\title{
Murathan Mungan'in Şairin Romanı romanında fantastik unsurlar
}

\section{İlyas SUVAĞĊi}

\begin{abstract}
APA: Suvağci, İ. (2019). Murathan Mungan'ın Şairin Romanı romanında fantastik unsurlar.
\end{abstract} RumeliDE Dil ve Edebiyat Araşttrmaları Dergisi, (14), 154-173. DOI: 10.2900o/rumelide.541007

\section{$\ddot{\mathbf{O} z}$}

Sanatçı, kimi zaman gerçeklere olduğundan farklı yaklaşıp ona estetik bir şekil vererek kimi zaman da gerçeklerden bunaldığı için onlardan kaçarak kendi kurduğu kumaca bir dünyaya sığınır. Sanatçı sınırsız hayal gücü sayesinde kurduğu bu dünyada sanatın gücü sayesinde gerçekleri daha soyutlaştırır ya da kendi hayal ürünü olan fantastik mekânlara da gerçek bir hüviyet kazandırır. Eserlerinde mitoloji, masal, efsane ve halk hikâyesi unsurlarını sıklıkla kullanmanın yanında bazı hikâye ve romanlarında fantastik unsurlara da yer veren Murathan Mungan 1980 sonrası Türk edebiyatında önemli şahsiyetlerden biridir. Mungan; şiir, tiyatro, roman ve hikâye gibi değişik türlerde birçok eser yazmıştır. Bizler de bu çalışmada onun fantastik tür kapsamında değerlendirilebilecek Şairin Romanı adlı eserini inceledik. Çalışmanın amacı fantastik türün ilkelerine bağlı kalarak romandaki fantastik unsurları tespit etmek, ayrıntılı bir şekilde kategorilere ayırıp belirlemektir. Buna göre söz konusu eserde sırasıyla; fantastik kişiler, mekânlar, zaman, olaylar, hayvanlar, bitkiler ve nesneler incelenmiştir. Çalışmada, veri toplama aracı olarak nitel araştırma yöntemlerinden olan doküman inceleme yöntemi kullanılmıştır.

Anahtar kelimeler: Fantastik, fantastik roman, Murathan Mungan, şairin romanı.

\section{Fantastic elements in the Şairin Roman}

\begin{abstract}
Artist takes refuge in a fictional world he has established himself sometimes by approaching the facts differently and giving the facts aestetic shapes and sometimes by escaping from them since get bored of facts. The artist abstracts the facts by means of power of unlimited imagination and art or gives a real character to the fantastic spaces which his/her imagination. Murathan Mungan has included fantastic elements in some of his stories and novels in addition to frequently using elements of mythology, myth, folk story and tale. So he is one of the important authors in Turkish literature after 1980. Mungan has written many works in different genres such as poetry, theater, novel and story. In this study, we examined the novel called Şairin Romanı in which can be considered within the context of the fantastic genre. The aim of the study is to determine the fantastic elements in the novel by categorizing in detail and abiding by the principles of the fantastic genres. From this point of view, fantastic people, spaces, time, events, animals, plants and objects in this novel have been respectively examined. In this study, document analysis method which is one of the qualitative research method has been used as data collection means.
\end{abstract}

Key words: Fantastic, fantastic novel, Murathan Mungan, şairin romanı.

1 Dr., Siirt Üniversitesi, Fen Edebiyat Fakültesi, Türk Dili ve Edebiyatı Bölümü, (Siirt, Türkiye), ilyassuvagci@siirt.edu.tr, 541007] 


\section{Giriş}

18. yüzyılda Aydınlanma Çă̆ıyla birlikte Batı dünyasında bilimin büyük bir önem kazanmasıyla her şey, nedensellik ilkesi doğrultusunda açıklanmaya çalışılır. Bu dönemde bilim, neredeyse tek 'gerçek' olarak kabul edilir ve onun katı gerçekliğinin hayata hâkim kılınmasıyla birlikte birey, farklı arayışlara yönelir. İçinde yaşadığı dünyanın gerçeklerinden kaçan birey, farklı dünyalara ait özlemlerini başka araçlarla sağlama yoluna gider. Bu arayışlar sonucunda bir "kaçış edebiyatı" olarak "fantastik edebiyat" doğar. Bu türde baskın olanın, dayatılanın aksine ötekinin hikâyesi önem kazanır. Yazarlar; bastırılan, görünmez kılınan ötekinin hikâyesini gün yüzüne çıkarır. Aslında bir nevi kendi özlemlerini yansıtırlar. Bu sayede artan örnekleriyle fantastik türün kabul görmesi sağlanır. Fantastik tür kabul gördükçe dünya genelinde türe yönelen yazar sayısında da artış olur. Türk edebiyatı açısından bakıldığında fantastik olarak nitelendirilebilecek örneklerin 1980'lerden sonra yaygınlaştığı söylenebilir.

Fantastik edebiyat, olağanüstünün olağan karşılandığı bir yazındır. Olaylar, kimi zaman gerçeğin ötesinde bir dünyada yaşanır kimi zaman da gerçek dünyada gerçeküstü niteliklere bürünür. Fantastik edebiyata konu olan unsurlar aklın, mantığın sınırlarını aşar, böylece neden - sonuç ilkesi çerçevesinde açıklanamayacak bir mahiyet kazanır. Burada esas olan olağanüstünün olağan karşılanmasıdır. Elbette bu olağanüstülükte hayali olanın payı vardır. Edebiyat da bir yaratma sanatı olduğuna göre burada sanatçının muhayyilesi devreye girer. Sanatçı bu düşselliği sağlamak için çeşitli unsurlardan yararlanır. Kimi zaman cinlerin hüküm sürdüğü bir mekân tasavvur edilir, kimi zaman da insanların göz açıp kapayıncaya kadar dünyayı dolaştı̆̆ bir mekânsızlık yaşanır. Bazen sihirli bir değnekle geçmişe ve geleceğe yolculukların yapıldığı bir zamansızlık sürer, bazen de devlerin, cinlerin, perilerin, hortlakların, şeytanların, meleklerin cirit attığı bir dünyada olağanüstü olaylar vuku bulur. Sanatçı, bu veya bunlara benzer olağanüstülüklerin kurgulandığı bir atmosfer oluşturarak eseri için gerekli olan düşselliği sağlar. Okurlar, bu düşselliğin kıyılarına yelken açarken artık fantastik bir âleme adım atmış olurlar. Elbette ki bu fantastik âlem yeni değildir. Öteden beri edebi metinlerde bu büyülü âlemin yansımalarına rastlanmaktadır. Hatta fantastiğin edebiyatla yaşıt olduğu da söylenebilir. Gılgamış Destanı'ndan Homeros'un Odeysseia'na; masallardan menkıbelere; halk hikâyelerinden Deli Dumrul'a kadar uzanan bir dizi eserde fantastiğin izlerini bulmak mümkündür. Ancak fantastiğin edebi bir tür olarak ortaya çıkışı, 18. yüzyıla rastlamaktadır. Jacques Cazotte'nin romanı Le Diable Amoureux (Âşık Şeytan) (1772)'ı ve Jean Potocki'nin Le Manuscrit trouvé à Saragosse (Saragossa'da Bulunan Elyazması) (1804) ile başladığı ve bir edebî tür hüviyetini kazandığı kabul edilen fantastik edebiyat, 19. yüzyılda E.T.A. Hoffmann ve Edgar Allan Poe'nin fantastik eserleriyle tüm dünyayı etkiler. 20. yüzyılda ise J.R.R. Tolkien Yüzüklerin Efendisi (1954-1955) adlı seri romanıyla fantastiğin tüm dünyada sevilen bir tür olmasını sağlar. Bu yüzyılda bilimkurgunun da dünyadaki en önemli temsilcilerinden biri olan ABD’li yazar Ursula K. Le Guin’i de unutmamak gerekir.

Türk edebiyatında ise fantastik unsurlara önce destanlarda, efsanelerde, masallarda, halk hikâyelerinde, menkıbelerde vb. türlerde rastlanır. Ancak bu tür, edebiyatımızın 19. yüzyılda Batı’ya açılmasıyla birlikte önemini kaybeder. Zira dönemin Tanzimat yazarları için önemli olan şey, esere gerçek hayatın yansitılmasıdır. Dolayısıyla burada hayali olana, olağanüstüne, fanteziye yer yoktur. Tanzimat dönemi sanatçlları, Giritli Ali Aziz Efendi'nin Muhayyelat (1852)'ını hedef tahtasına yerleştirerek bu türden eserleri saçma ve çocuksu bulmuşlardır. Bu nedenle bizde Batılı anlamda modern fantastik eserlerin çok geç bir dönemde ortaya çıktığı söylenebilir. Giritli Ali Aziz Efendi'nin Muhayyelât'ından sonra Ahmet Mithat Efendi'nin Çengi (1877)'si, Hüseyin Rahmi Gürpınar'ın Gulyabani (1913)'si ve Peyami Safa'nın Matmazel Noraliya'nın Koltuğu'yla (1949) ilk örneklerini veren Türk fantastiği, Nazlı Eray'ın eserleriyle yetkin örneklerine kavuşur. Türk edebiyatında özellikle 1980'den sonra önem kazanan fantastik 
edebiyat ürünleri çoğalmaya başlar. Bu alanda anlatılarıyla ön plana çıkan isimler olarak Nazlı Eray, Latife Tekin, Bilge Karasu, Buket Uzuner, İhsan Oktay Anar, Hasan Ali Toptaş, Sadık Yemni, Yavuz Ekinci ve Barış Müstecaphığlu'nu sayabilir; bunlara bazı hikâyeleri ve Şairin Romanı adlı eseriyle Murathan Mungan’ı da dâhil edebiliriz.

Murathan Mungan'ın Şairin Romanı eserini inceleyebilmek için öncelikle Nuran Özlük ve Barış Müstecaplığlu'nun fantastik türünün ne olduğuna dair görüşlerini aktarıp meseleyi açıklayalım. Türk Edebiyatında Fantastik Roman (2011) adlı kitabında Nuran Özlük, fantastiği iki türe ayırır:

"Birincisi fantastiğin yaşanan dünyada, bilinen gerçekliğin içine bilinmeyenin girmesiyle meydana gelmesi; ikincisi bilinen insan, mekân, zaman modelli evrenden farklı evrenlerin anlatılması. Yani biri İstanbul'da normal bir hayat sürdüren kahramanın hayatına hava perisinin girmesi, diğeri ise Orta Dünya gibi olmayan bir mekânda olmayan elf ırkının yaşaması” (Özlük, 2011: 28).

Başka kaynaklarda da fantastiğin türleri konusunda buna benzer sınıflandırmalar yapılmıştır. Sonuç olarak fantastiğin bu dünyada ve bu dünyanın dışında başka bir dünyada yaşanan olağanüstü olayların cereyan ettiği iki türü mevcuttur.

Fantastiğin, tür olarak kesin ölçütlerinin bulunmaması, fantastik romanın belirlenmesinde de güçlüğe neden olmaktadır. Dolayısıyla hangi romanın fantastik olduğunu, hangisinin olmadığını belirlemek pek de kolay değildir. Ancak yine de eserin ikliminden ve konuyla ilgili incelemelerde bulunan araştırmacıların tespitlerinden yola çlkarak birtakım ortak özelliklerden yararlanılabilir. Buradan hareketle fantastik romanın en genel özelliğinin olağanüstülük olduğunu söyleyebiliriz. Fakat olağanüstü nitelik taşıyan her anlatı da fantastik değildir. Nuran Özlük, fantastik romanı, tüm kuralların, gerçekliğin dışında bütünüyle hayal gücüyle oluşturulan anlatı türü olarak kabul etmektedir: "Bilinen, kabul edilen sosyal, siyasi, tarihî, bilimsel kuralların, genel geçer gerçekliğin dışına olağanüstü, doğaüstü unsurlarla alegorik anlamdan, düş, hayal, sanrı, delilik gibi psikolojik/psikiyatrik vakalardan tamamen arınmış bir hayal gücü ile çıkmayı mitos, efsane, destan, menkıbe, halk hikâyesi, masal vb. beslenerek ancak bu türlerin formatında değil, romana has unsurlarla sunan anlatı türüne fantastik roman denir" (Özlük, 2011:27).

Barış Müstecaplığlu, "Fantastik Kurgu ve Bazı Tanımlar” başlıklı yazısında, günümüzdeki fantastik kurgunun tamamen yazarın hayal dünyasında şekillendiğini şu ifadeleriyle ortaya koyuyor:

“20. yüzyllda gelișen fantastik kurgunun en önemli özelliği, anlatılan öykülerin gerçek dünyada değil tamamen yazarın hayal gücüne dayanan bir dünyada geçmesidir. Mitolojisi, coğrafyası, tarihi, rrkları, kültürü ile yani her detayıyla yazara ait bir dünyadır bu” (akt: Taş, 2009:7-8).

İster gerçek dünya olsun, isterse tamamen hayal ürünü bir dünya kurgulansın, fantastik anlatıda asıl olan olağanüstünün varlığıdır. Zira okuyucuyu meraklandıran olayların nerede geçtiğinden çok, nasıl olduğudur.

Assl şöhretini şiirlerine borçlu olan Mungan, tiyatro, hikâye ve roman türlerindeki eserleriyle de dikkati çekmektedir. Bu dikkat, yazarın 2011 yılında yayımlanan Şairin Romanı adlı fantastik romanıyla daha da artar. Aslında Murathan Mungan, daha önce yayımladığı Üç Aynalı Kırk Oda (1999) adlı hikâye kitabında yer alan "Alice Harikalar Diyarında", "Aynalı Pastane”, "Gece Elbisesi” hikâyelerinde fantastik unsurlar kullanır. Hatta bilinen masalların yeniden kurgulanmasıyla yazılan hikâyelerinde ve diğer bazı hikâye kitaplarında da bu unsurlara rastlanır. Fakat bütünüyle fantastik bir âlemde geçen Şairin Romanı, Mungan'ın bu türdeki ilk eseridir. 


\section{2. Şairin Romanı'nda fantastik unsurlar}

\subsection{Fantastik kişiler}

Şairin Romanı'ndaki ana karakterler Bendag, Moottah ve Gamen'dir. Fakat bu karakterler fantastik özellik taşımazlar. Üçünün de herhangi bir olağanüstü gücü, doğaüstü bir yeteneği yoktur. Romandaki fantastik karakterler yarı mecnun, yarı kâhin, yarı şair olan Ümma, kendi ikizleriyle biyolojik, fizyolojik, psikolojik tüm davranışları eş olan Zeey ve Tagan ve romandaki karşıt güç olan Agabu'dur. Bunların dışında doğaüstü güçlere sahip olduğuna inanılan "taşıyıcı çocuklar" ve yaptıkları olağanüstü işlerle ön plana çıkan "Rüya Terbiyecileri”"ne de ayrıca değinilecektir. Fakat romandaki fantastik karakterlere geçmeden önce ana karakterlerin birkaç cümleyle tanıtılmasında fayda vardır.

Bendag: Tam elli yll önce gönüllü olarak kendini Anakara'dan sürgün etmiş, bütün ömrünü yolculuklarla geçirmiştir. Yüz yaşına geldiğinde kendi yurdunda ölmek istemiş ve bunun için son yolculuğuna çıkar. Bu son yolculuk yazarın deyimiyle aynı zamanda Bilge Şair Bendag’nn son şiiridir. Bu yolculuktaki şiirlerini Son Yolculuk başlığı altında toplayacaktır. Bendag şiirleriyle Anakara'ya nam salmış, yıllarca şiirleri kale duvarlarında dalgalanmıştır.

Moottah: Anakara'nın en büyük şiir filozofudur. O da tıpkı Bendag'ın gönüllü sürgünlüğü gibi yıllarca kendini evine kapatır, hiç dışarı çıkmaz. Tam yirmi yıl boyunca evine kapandıktan sonra artık evinden çıkmaya ve bütün Anakara'yı gezmeye karar verir. Anakara'yı şehir şehir gezecek, her şehirde birkaç gün kalacak, konuşmalar yapacak, dersler verecek; şiir ve hayat konusundaki engin bilgi ve tecrübelerini insanlara aktaracaktır. Cadebra şehrindeki evinden çlkacağı bu yolculuğu On Üç Dolunaylı Yıl Şenlikleri'nin yapılacağı Odragend'de sonlandıracaktır. Bu yolculukta Zeey ve Tagan’ı da yanına çırak olarak alır.

Gamenn: Anakara'nın en ünlü, en gözde, en güvenilir polisidir. Açığa çıkarılması zor görünen vakaları çözmedeki başarısıyla meşhur olmuştur. Anakara'da iki polis tipi vardır: Atlı polisler ve şehir polisi. Gamenn atlı polislerdendir. Atı Sys ile birlikte geceler boyu Anakara'da dolaşır. Mesleğindeki ilk başarısını, adına "taşıyıcı çocuklar" denilen ruhları yıkanıp yeniden yerküreye gönderildiği düşünülen, öteki tarafa ait bilgileri ruhlarında kayıtlı olan ve bu kayıtlar gündelik bilgilerle karışıp silinmeden onları ele geçirmek için kaçıran gizli bir tarikatı ele geçirmekle kazanır.

\section{Ümma}

Şairin Romani'ndaki en önemli fantastik karakter Ümma'dır. Lelalu ile birlikte Anakara'nın en meşhur iki kadın şairinden biri olan Ümma, yarı mecnun, yarı kâhin, yarı şairdir. Onun kehanetleri çoğunlukla doğru çıkmakla birlikte her zaman tam bir tutarlılık içinde değildir; bazen yolunu şaşırır:
“Ümma’nın bütün zamanları aynı değildi; bu yüzden hiç olmayacak görünen kimi kehanetleri aynen söylediği gibi çıkmış, en imkânsız görünenler birebir gerçekleşerek herkesi hayretlere düşürmüş; kimi akla yatkın kehanetleri ise hiç gerçekleşmeyerek, gene aynı biçimde herkesi düş kırıklı̆̆ına uğratmıştı.” (s.15)

Diğer kâhinler ve büyücüler, Ümma’nın kehanetlerinin tutarlılık göstermemesinin sebebini, onun şair olmasıyla açıklarlar. Okuma yazma bilmeyen Ümma, şiirlerini içe doğuş halinde söyler. Diğer kadınlar onun şiirlerini yüksek sesle tekrar ederek ezberler. Ümma okuma yazma bilmediği için diğer şairlerin şiirlerini de bu kadınlardan dinler. Ümma'nın gözleri de pekiyi görmez. Normal bir insan yüzüyle 
kıyaslandığında iki gözü arasındaki uzaklık fazladır. Yüzüne bakanlarda ürküntü uyandırsa da ona doğaüstü güç kazandıran da bu özelliğidir. Yeryüzünü ancak kalp gözünün yardımıyla görebiliyordu.

Ümma'nın bir diğer özelliği taş, takı ve boncuk merakıdır. Anakara'da Ümma'nın takı, kolye merakını bilmeyen yoktur. Ümma, bazı özel zamanlarda değerli ve uğurlu taşlardan yapılmış bütün takılarını, yani bütün kolyelerini, gerdanlıklarını, bileziklerini, halhallarını, zincirlerini, iğnelerini, broşlarını, küpelerini, yüzüklerini, halkalarını takarak uyur. Ruhunu kaybetmekten korktuğu için, uykudayken ruhunun gövdesinden uzaklaşmasını engellemek için böyle yapar. Bendag'ın Anakara’ya adım attığı o ilk günün gecesinde de öyle yapar. Ümma, o gece "mavi bir rüya” görür. Rüyasında Bendag'nn Anakara'ya döndüğünü görür:

\footnotetext{
"Uyanırken dudaklarından kendiliğinden dökülüveren şu sözlerle Ümma bir kehanette bulunur gibi görüsünü dillendirdi:

'Bilge Şair Bendag döndü. Anakara’ya döndü, nihayet yurduna döndü.'

Bu sözlerle birlikte gözlerini açtı. Onun bu görüsü hemen yayıldı. İnanmadılar. Kimse inanmadı.

'Bendag elli yıl önce öldü,' dediler.

'Hayır,' dedi, ‘Ölmedi, yaşıyor ve döndü. Elli yıl önce yalnızca şiiri bırakmıştı. Ama kendisi hayatta ve çok uzun yollardan sonra nihayet Anakara'ya döndü” (s.12).
}

Ümma, rüyasında Bendag'ın sadece yurduna döndüğünü görmez; bununla birlikte bilge şairin yanında bir kadın olacağını, hayatının ikinci baharını yaşayacağını da görür. Gamenn’e yazdığı mektupta bu durumu şu sözleriyle ifade eder:

\begin{abstract}
"Umarım kehanet yorgunu gözlerimin gördüğü şu yoksul rüyalar bir parçacık da olsa ışık düşürüyordur aklının çıkmazlarına. Bu arada sırası gelmişken söyleyeyim, günün birinde Bilge Şair Bendag'la kesişirse yolunuz, olur da karşılaşırsan beklenmedik bir kavşakta, Anakara'ya ayak bastığının rüyasını gördüğümü söylemeyi sakın unutma ona. Biliyorum, döndüğü yol yumak olmuş içinde, ama bir zaman sonra bir kadın olacak yanında. Hayatın bitmediğini bir kez de onunla hatırlayacak bilge şair, büyük usta. Yıllar sonra bize suskunluğun uzun ve ketum yolcuğunun anlatacak.” (s.416)
\end{abstract}

Ümma, rüyaların gücüne inanır. Kâhin olmanın verdiği güçle geleceği, gelecekteki olayları rüyalarında görür. Ona olağanüstü bir güç kazandıran da bu yeteneğidir. Ümma’nın kehanetlerine "Fantastik Olaylar: Rüya” başlığı altında ayrıca değinilecektir.

\title{
Zeey ve Tagan
}

Şairin Romanı'ndaki diğer önemli fantastik karakterler Zeey ve Tagan'dır. Biri zeytin dalı esmeri, diğeri başak sarışınıdır. İkisi de dokuz yaşındadır. İkisi de ikizdir. İkisi de ikizleriyle tek bedenmiş gibi davranırlar. "Aynı anda kalkıyor, aynı anda oturuyor, aynı anda aynı adımı atıyor, aynı anda aynı eli aynı biçimde kaldırıyor, aynı anda aynı şeyleri söylüyor (...), başları bile aynı anda ağrıyor, çişleri bile aynı zamanda geliyor." (s.56) Bu durum zamanla onlar için tehlikeli olmaya başlayınca aileleri, onların bu durumuna bir çare aramaya başlar. Hekimlere, büyücülere, falcılara, kâhinlere başvururlar. Hepsi de aynı şeyleri söyler: "Ayırın bunları birbirlerinden," derler. "Çünkü bu eş zamanlı duygu ve davranışları zamanla deliliğe varan birebirlik halini almaya başlar" (s.56). Aksi takdirde böyle devam ederse birbirlerine köle olmuş ikizler haline gelirler ve böyle ikizlerin hayatı da birbirlerini öldürmeleriyle son bulur derler. Bunun üzerine aileleri Zeey ve Tagan'ı ikizlerinden ayırıp şiir filozofu Moottah'ın yanına çrrak olarak verirler: 
"İkisinin de benzer özellikleri varmış: kendilerine özgü tuhaf bilicilikleri, uçurtma uçurmadaki yetenekleri, içe kapanışları, otların ve bulutların alemlerine sokulmalarındaki tehlikeli hünerleri...” (s. 57)

İkizleriyle hareketleri, davranışları, tavırları; biyolojik, fizyolojik, psikolojik durumları tıpatıp aynı olan Zeey ve Tagan'ın ikizlerinden farklı olarak yapabildikleri tek bir şey vardır: Zeey, ikizinden farklı olarak uykusunda konuşur; Tagan ise ikizinden farklı olarak uykusunda yürür. Bunun dışında her şeyleri birebir aynıdır.

Davranışları, hareketleri, duyguları, karakterleri, her şeyleri ikizleriyle aynı olan Zeey ve Tagan'ın yakınlıkları tehlikeli noktaya varınca hekimler, falcılar, büyücüler, kahinler onların bu "İki kişilik yalnızlıkları tek kişilik yalnızlığa inene kadar” (s. 57) ayrılmalarının doğru olacağını söylerler. Çaresizlik içindeki aileleri birbirlerinden habersiz şehrin satrabı Fasuan'a başvururlar. Moottah'ın gözde öğrencisi olan Fasuan, biraz düşündükten sonra her ikizden tekinin Moottah'ın yanına çırak verilmesinin uygun olacağını söyler. Fasuan’ın ısrarıla ikna olan Moottah, “İki yarıdan bir bütün yapmak gibi bilinmedik başkalıkta yepyeni bir hayat şiiri” (s. 60) olabileceğini düşünerek bu teklifi kabul eder; Zeey ve Tagan’ı yanına çırak alarak Anakara yolculuğuna çıkar. Böylece birbirine bağlı görünen ikizlerin kaderi, eser boyunca olay örgüsünün düğüm noktasını oluşturarak heyecan ve gerilimi üst seviyede tutar, kitabın sonunda düğümün çözümlenmesiyle son bulur.

Şairin Romanı'nda da Gamenn'in kişilik bölünmesi yaşadığı, aynı anda iki kişi olarak çoğaldığı, başkalaşım geçirdiği görülür. Ancak Gamenn'in yaşadığı bu parçalanmış kişilik, ikizi Tagan'la bütünleşmesi sonucunda ve rüyalarında gerçekleşir. Bu anlamda Gamenn'in yaşadığı tam manasıyla bir ikizleşme değildir; çoğalıp bölünmesi, değişime uğraması söz konusudur. Bu durum sonucunda yaşadığı tuhaflıklar Gamenn'i rahatsız eder. Steinmetz'e göre "insanların psişik hayatlarındaki tuhaflıkları anlama çabalarının bir parçası olarak ortaya çıkan” ikiz motifi (Steinmetz, 2006: 35), Şairin Romanı'nda da benzer bir amaçla kullanılmaktadır. Cinayetlerin sırrını çözmek ve şairlerin katilini bulmakla görevlendirilen Gamenn, kendini bir anda cinayetleri işleyen katil olarak görür. Gördüğü düşlerden şaşkınlığa düşer, sürekli rolü değişir ve bir ikizleşme sürecine girer. Gamenn’in, Tagan'ın işlediği cinayetleri rüyasında görmesi, ikiziyle bütünleşmesinin bir sonucudur.

\section{Agabu}

Şairin Romanı'ndaki Agabu karşıt güçtür. Yeşilalaylar komutanı Settu'nun oğlu olan “Agabu” Necit yerlilerinin dağ dillerinde "baba" demektir. Yaşamı boyunca çok düşman edinen ve kendisinden önceki hiçbir komutanın kendi eceliyle ölmediğini çok iyi bilen Settu, kagemusha olarak adlandırılan kendisinin benzerlerini sürekli etrafinda bulundurur. Gerçek Settu'nun kim olduğu anlaşllamayacak kadar kendisine benzeyen kagemushalar sayesinde düşmanlarının kendisine yönelik olası tehdit ve saldırı girişimlerini bu şekilde bertaraf etmeyi planlar. Agabu daha küçücük bir çocukken Settu, oğlunu huzuruna çağırtır, kagemushaların arasına gizlenerek kendisini bulmasını ister. Agabu için bu durum tam bir işkencedir. Babasını tanıyamadığı için o kadar çok terler ki bütün ter bezlerinin çocukken kuruduğu, bu yüzden büyüdüğünde hiç terlemediği söylenir.

Agabu'nun karısı Zeheyra, Agabu'nun kendisini aldatması üzerine ondan intikamını almak için "Çölkabuğu” adı verilen bir bitkiden elde edilen bir zehir hazırlatır. Bu zehirle Agabu’yu hasta düşürerek onun boynundaki anahtarları almayı ve herkesten sakladığı sandığı açmayı planlar. Zeheyra planını uygulamaya koyduğunda Agabu günlerce hasta düşer. Çocukluğunda kuruduğu söylenen ve bir daha hiç terlemeyen Agabu'nun ter bezleri çözülür. Yıllardır hiç terlemeyen Agabu terden sırılsıklam olur, yılların 
terini birden üzerinden atar. Öyle ki, teri yatağını, odasını, evini su basmış gibi her tarafı sarar, evin içinde diz boyu yükseklikte yeşil göletler oluşur. Hizmetlilerin gün boyu evi temizlemesine rağmen Agabu'nun teri dinmez, yatağında, odayı diz boyu dolduran bir su içinde başıboş bir sal gibi yüzer:

"Sıra sıra dizilmiş kagemushaları arasında babasını tanıma sınavlarına çekildiği çocukluk günlerinden beri hiç terlemeyen, bunca yıldır zehrini içinden atamayan Agabu'nun terbezlerinin kilidi sonunda açılmış, yıllardır terleyemediklerinin hepsini birden terlemiş; tenini, yatağını, odasını, evini su basmıştı! Şimdi kendinde olmayan bedeninde sahipsiz kalmış korkuları, yıllardır içinden atamadığı koyulaşmış bir zehrin içinde başıboş yüzüyordu.” (s 285)

Çocukluğunda kuruduğu için ondan sonra yaşadığı süre boyunca hiç terlemeyen Agabu'nun, evi su basacak kadar terlemesi inanılması güç bir olaydır. Odayı kaplayan keskin ter kokusunu yazar sadece terin özelliğine bağlamaz; korkunun kokusu olarak değerlendirir: "Eti içeriden dağlayan korkunun kokusu!” (s. 286). Agabu'nun korkusu, bir gün her şeyin herkesçe bilineceğinden, her şeyin açı̆̆a çıacağından endişe etmesidir.

\section{Taşıyıcı çocuklar}

"Ruhlarında unutmanın sularından geçerken tamamen yıkanıp silinmemiş kayıtlı bilgiler olduğuna, (...) öteki âlemlere ait her şey(in) onların körpe dimağlarında saklı” (s.142) bulunduğuna inanılan çocuklara Taşıyıcı çocuklar denir. Bu çocukların, büyüklerin anlamadığı bir dille konuşmaları, anlaşılmaz sözcükler kullanmaları onların öteki tarafa ait sakladıkları gizlerin işareti olarak kabul edilir. İşte bu taşıyıcı çocukların körpe dimağlarında saklı bulunan öteki âlemlere ait kayıtlı bilgilerin gündelik bilgilerle karışıp kaybolmadan ortaya çıarmaya çalışan ve bu maksatla bu çocukları kaçıran gizli bir tarikat vardır. Söz konusu bu tarikat müritlerini, Anakara'yı dolaşarak bu çocukları arayıp bulmakla görevlendirir. Tarikat bilgeleri yaptıkları ayinlerle kaçırdıkları çocukların şifreli dilini çözmeye çalışırlar. Tabi her çocuk taşıyıcı çocuk değildir. Hangi çocuğun taşıyıcı çocuk olduğu tarikatın deneyimli üyeleri tarafından çeşitli aşamalardan geçirilerek tespit edilir. Ayrıca bu çocukların “ üç yaşından sonra oraya ait bütün bildikleri yerkürenin öğrettiklerinin enkazı altında kalacağından, bir daha o bilgilere saf ve temiz olarak asla ulaşılamayacağına inanıldı̆̆ için çocukların üç yaşını geçirmeden tarikat müritleri tarafindan kaçırılmaları ve ayin soruşturmasından geçirilmeleri gerekir” (s.143). Tarikat, kaçırdığı çocukları Sogranam kentindeki bir yer altı tapınağında saklı tutar. Kaçırılan çocukları bulma görevi verilen Gamenn, tarikatın yer altı tapınağını tespit eder ve çocukları kurtarır.

\section{Rüya terbiyecileri}

Aoi'deki Sağlık Yurdu'nda bulunan Rüya Terbiyecileri, rüyaları terbiye etme nitelikleriyle dikkat çekmektedirler. Onlara göre rüya içimizdeki bilinmeyen yabancı bir dildir. Bu dili öğrenmek, terbiye etmek, yaşamımızı yönlendirmek için rüyaları kullanmayı öğrenmek gerekir. Bunu da ancak Rüya Terbiyecileri yapabilir:

\footnotetext{
"Rüya Terbiyecileri’ ne gelince, onlar da rüyasının yükünü taşıyamayan, uykusunda yorulan, ruhu kararan, uykuda gördükleriyle boğuşan insanları kendi rüyalarıyla tanıştırıyor; insanın ham doğasının dili olduğuna inandıkları rüyayı sahipleri için terbiye ediyorlarmış. Onlara göre rüya başlı başına bir dildi, içimizdeki yabancı dil; onu öğrenmek, terbiye etmek, yaşamımızı yönlendirmek için onları kullanmayı öğrenmek gerekiyordu.” (s. 207)
}

Rüya terbiyecilerinin kullandıkları yöntemler bazen beklenmeyen sonuçlar doğurabiliyordu. Tedavi sırasında soma yapraklarının fazla çiğnenmesi, iyileştirme bahçeleri, ışık havuzları, rüyaların terbiye edilmesi sırasında kurbanların yaşadıkları sarsıntılar, yarılmalar, çeşitli sağaltım tekniklerinin 
istenmeyen sonuçları hastaları başka kimliklere büründürür. Kurbanlar, kendilerini bir başkası zannederek olağan yaşantılarına döndüklerine inanırlar:

\begin{abstract}
"Ne yazık ki geçmişte bazı terbiyecilerin yanlış teknik uygulamalarının sakat bıraktığı, kendisine geri dönemeyen vak'alar oldu. Örneğin bir zamanlar burada Khora diye gözükara, fazla aceleci bir sağaltman vardı, o da Kuyuhera gibi Wynmocklu'ydu, yeni teknikler denemekten, uyguladığ yöntemlerde risk almaktan çekinmezdi, kurban ve mağdur konumundaki bazı hastalar için uygulanan yer değiştirme ayinleri sırasında birkaç kişiyi geri getiremedi. Zavallılar 'o olmak' ile 'onu anlamak' arasındaki sınırda yarılıp kayboldular. Bütün bunlar yetmezmiş gibi yönetimden izinsiz olarak ortak rüya havuzu diye herkesi birbirine bağlayan tehlikeli bir yöntem denedi. Orada herkes birbirinin rüyasına sızabiliyor, hatta yönetebiliyordu." ( s. 213)
\end{abstract}

Sağllk Yurdu’nun yöneticisi Kuyuhera'nın kardeşi olan Khora, gözü kara, tehlikeli yöntemler denemeyi seven bir rüya terbiyecisidir. Hırslı, bencil ve başarıya aç bir kişilik sergileyen Khora, amacına ulaşmak için her yolu deneyenlerdendir. Kardeşi Kuyuhera’nın başarısını kıskanır ve onunla arasındaki farkı kapatmak için Remzganan ile Yasnura'yı (Tagan) ortak rüya havuzuna yatırır. Remzganan bu deneyden sağ çıkmaz. Yasnura ise kişiliğ̈ini, kimliğini, hafızasını yitirir. Khora, Yasnura'dan söz ederken onun kim olduğunu kendisinin (Yasnura) de bilmediğini, çocukluğuna ilişkin hiçbir şey hatırlamadığını, onun uydurduğu birçok adı ve birbirine benzemeyen birçok hayatı olduğunu ve hiçbir zaman kendisinin olmayan bir hayatı yaşamaya mahkûm olmuş bir talihsiz (s. 550) olduğunu söyler.

\title{
2.2. Fantastik mekânlar
}

\section{Anakara}

Yazar, "Yerküre" adında hayali bir gezegen yaratır ve bu gezegeni denizlerle, karalarla donatır. "Anakara" olarak adlandırılan yer, bu gezegendeki en büyük kara parçasıdır. Yerküre'deki çeşitli diyarlardan biri olan Anakara şehirleriyle, şiirleriyle, şairleriyle öne çıkmaktadır. Anakara'da yer alan şehirler şunlardır: Makrakamash, Ajnera, Micla, Eksularek, Odragend, Naburri, Cadebra, Dohanara, Serehudra, Udbera, Kohragandt, Sogranam, Aoi, Eddnabari, Cathay (ülke), Wynmock, Kırmızı Kent, Sohara, Samarakad, Vomaka, Sued, Pouhwek, Tau, Dragoman, Bahira, Zummorne, Janas, Pualajanas, LuuRa. Bu şehirlerin kale burçlarında ülke bayraklarının yerini şiir bayrakları almakta ve neredeyse Anakara'daki hemen herkes şiirle ilgilenmektedir. Şiirin, şairin büyük bir saygı gördüğü; şiir kahvelerinde, şiir meclislerinde, şiir toplantılarında şiir sohbetlerinin, şiir yarışmalarının düzenlendiği Anakara'daki şehirler fantastik mekânlar olarak tasvir edilmektedir.

Hayali bir mekân olarak tasvir edilen Anakara'daki şehirler farklı özellikleriyle ön plana çıkmaktadır. Önceleri kendi içine kapalı küçük ve şirin bir sahil kasabası olan sonraları büyük bir şehre dönüşen, Anakara'nın güneyinde yer alan ve Güney ışığıyla ünlü Makrakamash kenti; "On yetenek yedi sanat okulları" adı altında insan zihninin ve yaratıcılığının çeşitli yönlerinin sınandığı okullarıyla ünlü ve sırtoplayıcılarının kenti olarak bilinen Udbera kenti; bahçe hamakları, yaprak asmaları, kameriyeleriyle ve her müşterinin damak zevkine göre farklı harmanlarda özel olarak hazırlanan çayları ve çay evleriyle ünlü Naburi kenti; "Kehribar kırmak" anlamına gelen ve artık kimselerin bilmediği ölü bir dilden kalma "Kohra gagandt” sözünün zamanla kısaltılmış hali olan "Kohragandt” kenti; başkalaşım kayaçlarının bol bulunduğu bir bölgede kurulduğu için belirsiz güçler tarafından yönetildiğine, tekin olmadığına inanılan, oyunlarıyla ünlü Anakara'nın en renkli, en ışıkl, en çılgın kenti diye bilinen Aoi kenti; doğu dağlarının uzağında adeta bir masal ülkesi olan ve halk arasında öteden beri "Arık ülke" diye anılan Cathay; eskiden rüyaların atasının uyuduğu yer olarak bilinen ve hala yerküredeki her insanın gördüğü rüyaların geceleri oradan çıkıp geldiğine inanılan Wynmock kenti; gökyüzünün tam ve kusursuz bir 
kubbeyi andırdığı, sesin, gök katları aralanır gibi kutsal bir çınlayışla yankılandığı, tabiatın en uzun yatay çizgisi ve ufku bakış yoran büyük düzlüğün kenti Llasa; çevreyi kuşatan geniş bitki örtüsüne yayılmış ceviz, abanoz, armut, elma, şimşir, sedir ve gül ağaçlarıyla ünlü korulukları, ormanlık arazileri ve çoktan bir şehir büyüklügüne ulaşmış olmasına karşın hala köy adıyla anılan çok eski yerleşim birimlerinden biri olan Eddnabari; yazılı bir anayasası olan ve bu anayasanın yazılı bulunduğu her kopyanın insan derisinden yapılma zorunluluğu olan Anakara'daki birçok şehri, eyaleti kapsayan Tronteg İmparatorluğu; nar ağaçlarıyla ünlü ve hem gözyaşı hem nar tanesi demek olan Tau kenti; dilinde "Sen" diye bir hitap şekli olmayan hatta kendisinden bile "O" diye söz eden, "yıldız köpüğü" dedikleri mavi baloncuklu yağmurlarıyla ünlü Samofruna adaları; halk arasında "Güneşi ısıtmaz, rüzgârı üşütmez" şeklinde tabir edilen, Anakara'ya ait en kadim bilgilerin toplandığ "Zümrüt Belgeler" ve "El Mühürleri" adı verilen ilk antlaşmalar, ilk sözleşmelerin saklandığı, doğal bir yerleşim bölgesi olmaktan çok, fazla tasarlanarak kurulmuş, ruhsuz, kuru bir kent görünümünde olan LuuRa; otacıları, şifacıları, bol baharatlı sıcak şaraplarıyla ünlü, kentin orta meydanında "adalet ağacı" da denilen dev bir ejder ağacı bulunan, yılın belli bir mevsiminde "Ejderin gözünü aydınlatmak" denilen ışıklı törenler, oyunsu ayinlerle boydan boya kırmızıya boyandığı için rengiyle adlandırılan Kırmızı Kent; kuruluşu, şiirin ve yazının bulunuşundan bile eskiye dayanan, bulunduğu coğrafyanın bir armağanı olarak yılda bir kez gökyüzünde on üç dolunayın birlikte göründüğü tek şehir, hem yaşayan canlı bir şehir, hem açık bir müze görünümüyle Anakara'nın en büyük, en kalabalık, en tuhaf şehri olarak nitelenen, "ölü yaşatan”, "ortada duran", "açı şehir" anlamlarına gelen, "Odragend” kenti; "Gökyüzüne saçılmıss serpme yıldızlar gibi yerküre üzerinde sular ve denizlerin böldüğü çeşitli kara parçalarına kendi hikâyeleriyle dağılmış Raissa, Clarice, Leonia, Zoe, Bauci, Eusapia, Zemrude, Trude, Leandra, Adelma” (s. 217) kentleri.

Yazar, oluşturduğu fantastik mekânı, sosyal hayata yönelik kurumlarla donatarak kurgusal evreni gerçekçi kılmaya çalışır.

Bunların dışında Aoi'de, ruh sağaltıcılarıyla, rüya terbiyecileriyle ünlü, bir zamanlar Horad'ı iyileştirmiş olan "Sağlık Yurdu"; geçmişe dair birçok belge, harita, köprü, su kanalı, sarnıç, çeşme, sığınak, bina, yeraltı erzak depolarının, hatta eski savaş zamanlarında kaçmak için yapılmış yeraltı tünelleri çizimlerinin yanı sıra satraplar, komutanlar, şairler kadar suçlular, katiller, çeşitli suçlardan arananların usta kalemler tarafından çizilmiş portrelerinin bulunduğu "Çizimlerevi”; LuuRa kentinin simgesi sayılan Yılanlı Havuz Parkı; aynı anadan babadan olmadıkları halde birbirlerine "kardeş" diye seslenen ve birbirlerini gerçekten kardeş gibi hisseden çocukların barındığı; beslenmeleri, barınmaları, eğitimleri ortakana, ortakbaba denilen eğitmenler, gözetmenler tarafından sağlanan, sadece öksüz, kimsesiz ya da terkedilmiş çocuklar değil ana babalarıyla buraya gelip onları da başka çocuklarla paylaşan, kendileri de aynı biçimde başka ana babaların sevgi ve şefkatiyle sarmalanan çocukların da bulunduğu "Yaşam Ortaklaşma Evi”; Anakara'nın en büyük, en görkemli yapılarından biri sayılan yedi katlı ve yedi kapılı "Şehir Sarayı"; Odragend içindeki mesafe ölçülerine kerteriz alınan, her yerin ona göre tanımlandığı "Atalagaya Meydanı"; Odragend'in ana girişi sayılan, ilk çă̆ kadar bilge taşların arasından geçerek ilerlenen iki yanı heykellerle kaplı "Büyük Kapı" geçidi; değişik alanlardaki bilgileri ve birikimleriyle yerküre belleğinin koruyucuları olarak kabul ve saygı gören; tarihin, bilginin, deneyimin, belleğin, yerkürenin aktarıcıları olan, bilgelik ve düş yüklü bir dalgınlık içinde zamanı umursamayan yaşlıların bulunduğu "Limon Masası"; tamamı ilgi ve bakıma gereksinim duyan yaşlılara ayrılan geniş bir bölgede, yemyeşil korular arasına kurulan "Yaşlılar Yurdu" Anakara'daki sosyal yapılardır.

Anakara sadece şehirleriyle değil; gölleri, nehirleri, ırmakları, pınarları, şelaleri, dağları, tepeleri, ovalarıyla da fantastik bir mekândır. İşte Anakara'daki bu mekânlardan bazıları: İrili ufaklı yüzlerce gölün bulunduğu, bütün yıl boyunca yalnızca tek bir mevsim yaşayan, perileriyle ünlü Dargın Gölleri; 
yerkürenin en derin, en durgun gölü olduğu söylenen, suyu başka hiçbir yerde rastlanmayan sis mavisi rengindeki Balma Gölü; gümüş sularıyla ayağı kendisine değen atları kanatlandıran Smna Irmağı; genişliği sebebiyle üzerine köprü kurmaya elverişli olmadığından ulaşımın sallarla yapıldığı çağla yeşili renginde akan, bol köpüklü Anydra Nehri; rengi hep bulanık aktığı, tepelerden bakıldığında güneşte kurumuş bir kemiği andırdığı için Kemik Nehri olarak adlandırılan nehir; şifalı olduğu söylenen suyu, birçok hastalığı iyileştirmede hekimler ve büyücülerce kullanılan Dokuz Boğum Pınarları; Anakara'nın en güzel sıradağ adı olan Gençlik Dağları ve Gençlik Dağları'nın yükseklerinden görkemli bir sadelik ve sükûnet içinde dökülen sis şelaleri; tamamen tuzdan yapılmış olan Tuz Dağı; birbirlerinin omuzlarına başlarını yaslıyormuş gibi yan yana sıralanmış bir dizi tepeden oluşan Kızıltavşan Tepeleri; masmavi bir mucize gibi dalgalanan uçsuz bucaksız mavi kamass çiçeği ovası; şairlerin yanlış kuyulara seslenerek kendilerini kandırdıkları ve böylelikle kendileri için yalancı şairlik ömrü çaldıkları söylentilerinden adını alan Kandıran Kuyular; sevgililerin, gidene oradan el salladığı, gözden ırak vedalaşmaların, başkalarına gösterilmek istenmeyen gözyaşlarının, denize atılan mendillerin tanı̆̆ı olan Elveda Kayası; insanların unutmak istedikleri şeyleri bağıra bağıra söyledikleri Unutma Kayaları.

Anakara’nın bir diğer özelliği on üç dolunayın yerkürede bir tek burada görülmesidir:

"Bu nedenle Anakara'da yerkürenin diğer bölgelerinden farklı olarak on üç dolunaylı yıl takvimi kullanılırdı. Ayrıca buradaki gökyüzünün yerkürenin diğer kara parçalarıyla paylaştığı dört dolunayı daha vardı ve her yıl yalnızca bir kez Anakara'da, Odragend'de gökyüzünde irili ufaklı on üç dolunay birden olur, her yer gümüș rengi bir gündüz aydınlığıyla ışırdı. Hiç kimsenin uyumadığı o gece doğanların bahtının çok açık olduğuna inanılırdı. Her bir dolunayın ayrı bir adı ve kısmeti vardı." (s. 34)

\section{Şairin kuyusu ve kandıran kuyular}

Ütopik bir yer olan Anakara'daki en önemli fantastik mekân "Şairin Kuyusu"dur. Şairin Kuyusu, şairlerin şairliklerini tescil ettirdikleri bir mekândır. Yerkürenin en derin kuyusudur. "Şairin Kuyusu'nun geçmişi ta yeşil kanlı devlerin, kırmızı dilli ejderhaların yaşadıkları söylenen zamanlardan kalma eski ve kutlu bir söylenceye dayanır" (s. 87). Geleneğe göre genç şairler özgün şiirler ortaya koyduklarında, şiirlerinde kendi seslerini yakaladıklarına inandıklarında kuyunun başına varıp şiirini kuyuya okur. Eğer şiirinde kendi sesini bulmuşsa kuyu, şiiri, şairin sesiyle geri yankılar. Böylece onun şairliğini tanımış olur. Eğer şairin şiirinde başka şairlerin sesi varsa bu kez de onların sesiyle yankılar. Bu şekilde de onların şairliklerini kabul etmediği anlamına gelir.

Tabi kuyunun bir de adabı var. Şiirini kuyuya okuyan şairin yanında kimse bulunmaz. Şair kuyuyla baş başa kalır, kimse onların ne konuştuklarını duymaz. Amaç, şiiri kendi sesiyle yankılanmayan şairlerin mahcubiyetlerine tanık olmamaktır. Bu maksatla kuyunun çevresine kireç taşlarıyla geniş bir halka yapılmış, kuyunun başında biri varken kimse o halkanın içine girmez. Böylece şair kuyunun ağzında kendi yazgısıyla baş başa bırakılır.

Şairin Kuyusu'nun bulunduğu bölgeye “Kuyular Bölgesi” denir. Onlarca kuyunun bulunduğu bu bölgede bir de "Kandıran Kuyular" var. "Kandıran Kuyular bölgesi adını, çok eskiden şairlerin yanlış kuyulara seslenerek kendilerini kandırdıkları ve böylelikle kendileri için yalancı şairlik ömrü çaldıkları söylentilerinden almıştı. Hem doğayı, hem insanları kandıran hileci bölge olarak bilinirdi burası. Kandıran Kuyular kuşaklar boyu kim bilir kaç şairi, kaç kulağı kandırmıştı?” (s. 83-84)

Agabu, Serhenas’ı öldürtüp onun herkesten gizlediği şiirlerini kendi şiirleriymiş gibi belli aralıklarla ortaya çıkarır. Bu şiirler sayesinde şairliği herkesçe takdir edilir, büyük bir üne kavuşur, şiirleri yıllarca 
şehrin surlarındaki bayraklarda dalgalanır. Ylllar sonra karısı Zeheyra, Agabu'nun bu sırrını ortaya çlkarır ve onun çaldığı Serhenas'ın şiir defterlerini Moottah'a verir. Moottah defterleri aldıktan sonra ilk iş olarak bu şiirleri Şairin Kuyusu'na okumaya gider. Amacı, şiirlerin Serhenas'ın sesiyle yankılandığını, onun kendi sesini bulmuş bir şair olduğunu Şairin Kuyusu'ndan dinlemektir. Bir gerçeği kanıtlamaktan ziyade onun aziz hatırasına bir vefa borcu olarak yapar bunu. Nitekim şiirleri Şairin Kuyusu'na okuduğunda Serhenas'ın sesi kuyunun dibinden dalga dalga yükselir. Bu açıdan bakıldığında şairlerin şairliğini tescil eden Şairin Kuyusu'nun ve yalancı şairleri yanıltan Kandıran Kuyular'ın fantastik nitelikler taşıdı̆̆ı söylenebilir.

\section{Udbera kenti, Tereddüt köprüsü ve Kasreina yolu}

Udbera, sırtoplayıcılarının kenti olarak bilinir. Köy köy gezen sırtoplayıcıları gezdikleri yerlerdeki insanların sırlarını toplayıp defterlere yazar, sonra bu sırları sırtlayıp Udbera'ya getirirler. Tereddüt Köprüsü’nün öte yakasında bulunan Udbera'ya geçtiklerinde bu sırların bazıları bu köprüden geçerken tereddüde düşer, yazılı oldukları defterin sayfalarından kendiliğinden silinir. Sırtoplayıcaları köprüyü geçip Udbera'ya giden Kasreina Yolu’na tırmandıklarında defterlerin çoğu sayfası boş çıkar. "Buranın ahalisinin, insanoğlunun unutma gücünü 'kasreina' diye adlandırması bu yüzdendir. Kederlerini geride bırakmak, yaşamını kaldığı yerden sürdürmek isteyen insanlara öteden beri Kasreina Yolu'nu tırmanması söylenir” (s. 111). Udbera Kenti, Tereddüt Köprüsü ve Kasreina Yolu üçlüsü; sırların toplanması, köprüden geçerken bazı sırların tereddüde düşüp silinmesi ve sırtoplayıcıların defterlerinin boş olduğunu görüp hayata kaldıkları yerden devam etmek için Kasreina Yolu’nu tırmanmaları bakımından fantastik özellikler taşır.

\section{“Işık Havuzu”, “Yankı Odası” ve “İyileştirme Bahçeleri”yle Aoi’deki sağlık yurdu}

Aoi’deki Sağlık Yurdu, ruh sağaltıcıları, Rüya Terbiyecileri ve tedavi yöntemleriyle oldukça ilginç bir yerdir. Sağlık Yurdu, "insanın içinin hasarını onarıp, ruhunu güçlendirip korkularını yenerek yeniden yaşamına döndüğ̈̈” (s. 206) bir mekân olarak karşımıza çıkmaktadır. Şehrin çıkışındaki büyük korulukta, eğimli bir tepeye konumlanan yurdun büyük, huzurlu binalarında "ruh sağaltıcıları, Rüya Terbiyecileri, otacılar yaşar, kendilerine ihtiyaç duyan insanlara çeşitli konularda yardım ederler" (s. 203-204). Kirlenmiş algıların yıkandı̆̆ı "Işık Havuzu", insanların geçmişin sesini dinledikleri "Yankı Odası” ve “İyileştirme Bahçeleri” Sağlık Yurdu’nun fantastik mekânlarıdır:

"Girişteki dört yanı camla kaplı yüksek kubbeli iç avluda büyük bir masa çevresinde yarım ay biçiminde dizilmiş, rahat koltuklara yayılmış, birörnek giysiler içinde kadınlı erkekli bir grup insan gördüler. İlk bakışta öldürücü bir kederin pençesinde kıvranan, ruhları sakatlanmış kişiler gibi görünmeseler de hallerinde tuhaf bir esriklik vardı. Kendine özgü tartım taşıan törensi bir hava içinde önlerindeki masaya uzanıp doğruluyor, masanın üzerinde sıralı duran sıkıştırılmış talaş ve bambu liflerinden yapılma yayvan kaplardan aldıkları soma yapraklarını çiğniyorlardı. Tabakları tepeleme dolduran bu dalcıkları yapraklarından alışkın hareketlerle sıyırıp soyarken bir ayinin gereklerini yerine getiriyor gibiydiler. Esrimenin solgunlaştırdığı yüzlerinde ortak bir dalgınlık, ama bakışlarında her birinin kendi iç âlemine kapanmış olmasının farklılı̆̆ı vardı.” (s. 204)

Pepqemok’un “Bunlar ne çiğniyorlar?” sorusu üzerine:

"Moksha bitkisinden yardım alıyorlar," dedi onlara yol göstermekle görevli Jink. "Gerçeğin üzerindeki örtüyü kaldıran bitkilerin yapraklarını çiğnemek eski bir alışkanlıktır. Gözümüzü, aklımızı ve ruhumuzu zenginleştiren soma yaprakları bize algı kapıları açar. Bizi evren karşısında sakinleştirir." Az ileride "Işık Havuzu" dedikleri her bir yandan ışık alan piramit biçimindeki cam bölmedekileri göstererek, "Burada da kirlenmiş olan algılarını yıkıyorlar," dedi Jink. Camdan dışarıda belirsiz bir yeri gösterir gibi geniş bir el hareketiyle, "Bulunduğumuz binanın arka tarafına 
düşen bu geniş arazide de ‘İyileştirme Bahçeleri’ bulunuyor. Açıçası ben hepimizin bu bahçelere ihtiyacı olduğunu düşünenlerdenim. En azından yılın önemli bir bölümünde...” (s. 205)

Sağlık Yurdu'nun yöneticisi Kuyuhera'dır. Rüya terbiyecilerinin piri sayılan Wynmock'lu Kuyuhera, memleketinden söz ederken rüyaların atasının orada uyuduğunu, insanlık tarihinin rüyasını gördüğünü ve her insanın gördüğü rüyanın oradan çıkıp geldiğini belirtir:

"Benim geldiğim yer olan Wynmock eskiden rüyaların atasının uyuduğu yer olarak bilinirmiş. Hala yerküredeki her insanın gördüğü rüyaların oradan çıkıp geldiğine inanılır. Rüyaların atası, bütün bir insanlık tarihini rüya olarak görmüş orada. Belki de bizim hayat diye yaşadığımız onun bir rüyasıdır yalnızca. Çok önceleri gördüğü, belki de çoktan unuttuğu bir rüya...” (s. 208).

Ruh sağaltıcılarıyla, rüya terbiyecileriyle ünlü; "Işık Havuzu", "Yankı Odası" ve "İyileştirme Bahçeleri”yle bilinen Sağllk Yurdu fantastik bir mekân görünümündedir.

\section{Quarrin ve Avaquarrin sıradağları}

Quarrin ve Avaquarrin Sıradağları, gerek kutsal metinlerde yer alan gerekse de Gılgamış Destanı'nda geçen Nuh Tufanı ve Nuh'un Gemisi hadisesiyle paralellik göstermektedir. Yüksekliğiyle bulutlara erişen Quarrin Dağları ve yüksekliği bulutları da geçen Avaquarrin Dağları, bu mitolojik hikâyeye göndermede bulunma işleviyle yer almaktadır. Bölge halkının inanışına göre yerkürenin sular altında kaldığı büyük tufan sırasında, daha sonra soylarını devamını sürdürecek canlıların içinde bulunduğu Shunn gemisinin, sular çekildikten sonra Avaquarrin doruklarına oturduğu söylenir. Fakat Avaquarrin Dağları o kadar yüksektir ki bugüne kadar oraya çıkabilen olmamıştır. Ölümün oradan geldiğine ve oraya döneceğine, eğer oraya çıkabilseler orada tüm insanlık tarihinin iskeletini bulacaklarına inanırlar. Görüldüğü gibi isim değişikliği dışında Nuh Tufanı'ndan hiçbir farkı olmayan bu hadise, ütopik bir mekân olan Anakara'da da yer almaktadır. Yazar, tümüyle kendine özgü, eşsiz, benzersiz hayali bir gezegen yaratmamış, bu dünyadaki olgu ve olayları da oraya yansıtarak Anakara'daki inançların kökenine dayanak oluşturmuştur.

Yaşadığımız dünyadan tamamen farklı bir mekân kurgusuyla okurun karşısına çıan Şairin Romanı, bu yönüyle modern hayatın kıskacındaki bireylere yeni bir yaşam alanı açar. Fantastik, ütopik mekanlarıyla dikkat çeken eser, beton yapılar içerisine sıkışıp kalmış, tabiattan uzaklaşmış bireyleri ve toprağa ayak basmadan yetişen yeni nesilleri doğayla bütünleşmeye davet eder. Kendisiyle yapılan bir söyleşide Mungan da kitabın bu yönüne özellikle dikkat çeker:

"Bu kitabın, kâinatın nabzından kopmuş, tabiatla ilişkisini kesmiş, beton, çelik ve camdan örülü bir uygarlık içinde kendi fanusunu örmüş insanlara nefes alma sahası açtığını fark ediyorum şimdi. Bu benim büyük edebiyat ödüllerimden biri."2

\subsection{Fantastik zaman}

Şairin Romanı’ndaki zaman, yüklendiği bir takım özellikler açısından mitolojik bir zamana göndermede bulunur. Gerek romanda anlatılan toplumun yaşayış tarzı gerekse de kâhinlik müessesesinin toplumun inanç sistemindeki varlı̆̆ mitolojik devirleri yansıtır:

"Romandaki bazı tasvirler ve eserde anlatılan toplumsal yapı, okuyucuyu, inanç sisteminde tabiatın büyük rol oynadığı, kâhinlik müessesesinin kabul gördüğü, çok tanrılı inançların hâkim olduğu mitolojik bir zamana götürür. (...) Şairin Romanı; anlatılan mekânlar, toplumsal yapı, kahramanların yaşayış tarzları ve inanç sistemleri açısından günümüz dünyasından çok mitolojik dünyaya

2 http://egoistokur.com/murathan-mungan-sol-hulyalari-olan-bir-yazarin-utopyasini-yazdim/ 
göndermeler yapar ve okuyucuya çok farklı kültürel ögelerle yorumlanabilecek bir dünya sunar" (Yüksel, 2012: 25-28).

Şairin Romanı'nda iki zaman var: Aktüel zaman ve geçmiş zaman. Bendag ve Gamenn’in paralel ve eş zamanlı yolculukları aktüel zamanda gerçekleşirken, Moottah ve çırakları Zeey ve Tagan'ın yolculukları ise geçmiş zamanda gerçekleşmiştir. Her iki zamanda da geriye dönüşlerle olaylar genişler.

Fantastik bir roman olan Şairin Romaninda nesnel zaman belli değildir. Fakat olayların yaşandığı zamanı "kadim" zamanlar olarak değerlendirmek mümkündür. Sevda Şener'e göre olayların geçtiği “zaman ve mekân endüstrileşme öncesinin Avrupa'sını anımsatıyor” (Şener, 2012). Oylum Yılmaz’a göre ise "Bendag'ın, Moottah’ın, Gamenn’in Anakarası, hemen hiçbir okurun gözünden kaçmayacak biçimde Anadolu'yu, Anadolu'nun çok kültürlü yapısını anımsatıyor” (Yılmaz, 2011). Murathan Mungan da kendisiyle yapılan bir röportajda, "Künt kapıları anlatırken Moottah, bilenler aslında onun bir Selçuklu mimari geleneği olduğunu anlarlar” (Erciyes, 2011) der. Şairin Romanı, fantastik kurgusuyla birlikte yukarıdaki açıklamalar ışığında göz önüne alındığında olayların zamanının 12-13. yüzyıllar dönemini anımsattığı söylenebilir.

Yaşadığımız dünyadan farklı bir mekân olarak tasvir edilen Anakara, zaman unsuruyla da farklı özellikler arz etmektedir. Anakara'da yıllara özel adlar verilir, her yılın ayrı bir adı vardır. Mesela,

“Çağlayan Gümüşü Yılı” (s. 226)

“Ay Bükülmesi Yılı” (s. 226)

“Başak Dalgını Yılı” (s. 226)

“Uçsuz Akşam Solgunluğu Yılı” (s. 226).

Yılların özel adları gibi mevsimlerin, ayların, günlerin hatta saatlerin bile özel adları vardır. Örneğin,

“Mevsim ejder ağacının kut mevsimiydi.” (373)

“Su ayına karşıllk düşen günler” (s. 211)

“On dördüncü ayın on ikinci gününün kaplan saati” (s. 210)

"Onunla son görüşmesinin üstünden ikinci güneş takvimiyle en az on beş, yirmi yıl geçmiş olmalıydı" (345).

Kişileriyle, olaylarıyla, mekânıyla fantastik bir görünüm arz eden Şairin Romanı'nda zaman, bu unsurlarla paralellik gösterir.

\subsection{Fantastik olaylar}

\section{Rüya}

Tüm rüyaların fantastik bir olay olduğunu söylemek mümkün değilse de Şairin Romanı'ndaki kimi rüyalar, gelecekten haber veren, ileride neler olacağına dair bilgi veren özelliğiyle dikkat çekmektedir. Bu yönüyle eserdeki bazı rüyalar fantastik unsurlar barındırır. Bu konuda özellikle rüyalarıyla ön plana 
çıan isim ise Ümma'dır. Bir rüyasında Bendag'ın Anakara'ya döndüğünü gören Ümma, bir başka rüyasında katilin Gamenn olduğunu görür. Fakat bu rüyada tuhaf bir durum var: Hem bıçağı sallayan el hem de ona engel olan el Gamenn'indir. Ümma'nın rüyasında Gamenn aynı anda, tek bedende iki kişi olarak görünür:

"Gamenn’in dört kolu vardı ve tek bedenden yere iki gölge birden düşüyordu. Biri bıçak sallarken diğeri tutuyor, biri yüzünü açarken, diğeri saklıyordu. Gölgelerden biri ayaklanıp yerden kalktı, ayaktaki gövdenin içine saklandı. Bıçağın yere, diğer gölgenin üzerine düşmesiyle birlikte gölge kayboldu, her şey yeniden karanlıkta kaldı." (s. 359)

Ümma’nın rüyasında gördükleri biri Gamenn, diğeri de ylllar önce Moottah ve Zeey ile birlikte öldürüldüğü zannedilen Gamenn’in kardeşi Tagan'dır. Tagan, katillerin elinden kurtulmayı başarır fakat bir meczup olarak hayatını sürdürür. Yıllar önce Moottah ve Zeey’i lime lime eden katiller gibi şimdi kendisi şairleri öldürerek etlerini parça parça sağa sola savurmaktadır. Onu yakalamakla görevlendirilen ise Gamenn'dir. Yani Ümma’nın rüyasında gördüğü katil Tagan, ona engel olan ise kardeşi Gamenn'dir.

Gamenn’i bu şekilde rüyasında gören başka biri ise, onu daha önce hiç tanımayan Aoi Şenlikleri Yöneticisi Başkanı Dynn'dur. Dynn, ortak rüya havuzu deneylerine katılır, Gamenn’i bu ortak rüya havuzu rüyalarında görür. Dynn, rüyalarında Gamenn'in çok kişilik değiştirdiğini, onu kendisi olarak değil, bir başkası olarak gördüğünü söyler. Daha sonraki karşılaşmalarında Dynn, Gamenn’e rüyasını anlatır:
"Sürekli tekrarlanan imgelerinizin birinde yüksekten, çok yüksekten düşüyordunuz, yarı baygın bir halde üstü kapalı arabalarda oradan oraya taşınıp kaçırılan çocuklar görüyordum. Sakin geçen günlerinizi vahşet ve şiddet dolu günler izliyordu. Sonra elinizdeki bıçağı kuytu köşelerde sıkıştırdığınız birilerinin boynuna, yüzüne saplıyordunuz! Ne zaman birini öldürseniz, öldürdüğünüzü unutup çocuk oluyordunuz, ta ki yeniden büyüyüp yeniden birilerini öldürene kadar... Assl ürküncü siz kim olduğunuzu sahiden bilmiyordunuz! Bir adınız, bir geçmişiniz, kendinize ait sahici hatıralarınız yoktu. Hem kendinizi arıyordunuz, hem öldürmek için birilerini. O karanlık rüyalardan size ait tek aydınlık an olarak hatırladığım bir kar kızağı var, kendine ait bir adı olan ve sizin sürekli olarak o adı sayıkladığınız bir kar kıză̆ı, sonra bir de yüzünüzde derin bir yara.. İçine bütün benliğinizin, belleğinizin gömülmüş olduğu bir derin yara... Yaranız zamanla belleğiniz olmuş." (s.512-513)

Tipkı Ümma gibi Dynn’un da rüyasında gördüğü biri Gamenn, diğeri kardeşi Tagan'dır. Çocukları kurtaran Gamenn, birilerini öldüren Tagan; sakin günler geçiren Gamenn, şiddet ve vahşet dolu günler yaşayan Tagan'dır. Dynn'un bahsettiği kar kızağı ise Serhenas'ın "Roasanayma” adını verdiği kızaktır. Mottah, çırakları Zeey ve Tagan'a arkadaşı Serhenas'ın kızağından söz eder, bu durum daha önce hiç kar görmeyen Zeey ve Tagan'ın çok hoşuna gider. Birlikte bir kızak yapmayı planlarlar. Ancak Mootah ve Zeey, Agabu tarafından öldürtülür, Tagan ise uçuruma atlayarak kurtulur. Hayatına yarı meczup bir şekilde devam eden Tagan, "Roasanayma” adını sürekli sayıklar. Dynn'un, Gamenn’in yüzünde gördüğünü söylediği yara ise Tagan'ın yüzündeki yaradır. Tagan, uçuruma atlamadan önce uğru çetelerinin bıçak darbelerine maruz kalır.

Ümma’nın bir başka rüyası ise o yıl, On Üç Dolunaylı Yıl Şenlikleri’nde olacakları önceden bilmesidir. Ümma, rüyasında On Üç Dolunaylı Yıl Şenlikleri’nde büyük sürprizlerin yaşanacağını, her şeyin açığa çıacağını, sırların çözüleceğini, gizli hiçbir şeyin kalmayacağını şu sözleriyle dile getirmektedir:

"O gün, on üç dolunaylı göğün altında birden fazla şey olacak; gök katlarındaki on üç ayrı kaynaktan akan gümüsşten sicimlerle birden fazla giz ışığa çıkacak. Hakikatin yüzü birkaç yerinden birden aydınlanacak. O gün çok kişi gülüp az kişi ağlayacak. Yeryüzündeki her kuyu kendi sesiyle konuşup, her yol kendine katlanıp kaynağına kavuşacak. Başlangıcın ışı̆̆ı, hakikatin bilgisi adeta on dördüncü dolunay olup parlayacak." (s. 416) 
Bendag'ın Anakara'ya döndüğünü rüyasında gören Ümma, bir başka rüyasında ise Bendag'ın yanında bir kadın olacağını görür. Ümma'nın rüyasında gördüğü Bendag'ın yanındaki kadın Ulsangeyma'dır. Bir keçe işçisi olan Ulsangeyma, Bendag Anakara'ya döndüğünde onu görür ve onunla sohbet eder. Bendag adını, kimliğini, gerçeğini bir tek Ulsangeyma'dan saklamaz. Bendag daha sonra On Üç Dolunaylı Yıl Şenlikleri'ne katılmak üzere Odragend'e gittiğinde Ulsangeyma da onun peşinden Odragend'e gider. Burada Bendag'la Ulsangeyma arasında bir yakınlaşma başlar. Ümma, Odragend'den çok uzak bir yerde, Ajnera'da bu olayı da rüyasında görür.

Bendag, Odragend'de bulunduğu bir gecede rüyasında Ümma'yı görür. Ümma Bendag'a, Anakara'ya ayak bastığı ilk gün onu rüyasında gördüğünü ve nihayet şu anda ikisinin aynı uykuda, aynı rüyada buluştuklarını söyler. Ayrıca Bendag'ın atlı polis Gamenn’i bulup ona her şeyi anlatmasını söyler.

Rüyalarıyla ön plana çıan karakterlerden biri de Gamenn'dir. Olayları katilin gözünden gören Gamenn bu durumdan rahatsızdır. Katilin gözlerinin onun rüyalarını ele geçirdiğini düşünen Gamenn, gördüğü rüyalardan ötürü suçluluk duygusuna kapılır. Ümma'yla bu konuyu konuştuğunda bundan duyduğu rahatsızlı̆̆ , huzursuzluğu, suçluluk psikolojisini dile getirir:

"Kendim işliyormuşum gibi acı çekiyorum o cinayetleri seyrederken... Ayırt edemiyorum. Gören göz benim ama bıçağı sallayan el benim mi? Sanki başkasının gözlerini ödünç almışım. Ya da bir başkası benim gözlerimi kullanıyor öldürmek için. Azap içinde uyanıyorum her seferinde. Sanki gözlerim değil de kendim olsaydım orada, kimse ölmezdi, diye.” (s. 137)

Gerek Ümma'nın gerekse de Gamenn ve Dynn'un rüyaları Şairin Romanı'nda fantastik bir yapıya sahiptir. Romanda rüya motifi, kehanetle birlikte değerlendirilir. Ümma, rüyaları vasıtasıyla hem Bendag'ın Anakara'ya döndüğünü görür hem On Üç Dolunaylı Yıl Şenlikleri’nde yaşanacakları bilir hem de şairlerin katilini bulması için Gamenn'e yardımcı olur. Ümma ayrıca Bendag'ın rüyasına girerek onun Gamenn'le görüşmesi, ona her şeyi anlatması konusunda onu uyarır.

\section{Yerine geçme ayini}

Aoi'deki Sağllk Yurdu'nda uygulanan bir tedavi yöntemidir. Başlangıçta bir tören unsuru olarak ortaya çıan "yerine geçme ayinleri” zamanla ruh sağaltma yöntemi olarak kullanılır. Bu ayinlerde kurban olarak nitelendirilen kişi çeşitli tekniklerle saldırganın yerine geçirilerek onun düşmanını tanıması, anlaması hatta bağışlaması sağlanmaya çalışılır. Sağlık Yurdu'nun yöneticisi Kuyuhera'ya göre "her türden kurbanın özgürlüğü, celladını bağışlamasına bağlı”dır (s. 207).

Yerine geçme ayinlerinde korku, kaygı ve sıkıntılardan arınmasını sağlamak için geliştirilen çeşitli tekniklerle kurban bir süreliğine saldırganın yerine geçirilir, böylelikle düşmanını tanıması, anlaması hatta bağışlaması sağlanmaya çalışılır.

\section{Rüya havuzu}

Yerine geçme ayinine benzer bir uygulamadır. Burada kurbanlar, mağdurlar birbirinin rüyasına sızabilir hatta birbirlerinin rüyalarını yönetebilir. Rüya havuzu uygulaması şöyledir: İnsanlar, derinliği iki-üç karışı geçmeyen bir havuza sırtüstü uzanıp uykuya dalar. Herkesin yalnızca kendisine ait bir Toteh kristali var. Bu kristal onların duygularını, düşüncelerini, hayallerini, hatıralarını saklar, bir nevi kişisel kayıt işlevi görür. Sahibiyle algısal ilişkiye geçen kristale bir başkasının dokunması halinde bu algı bulanır, kirlenir, hatta hasara uğrar. Bir başkasının dokunmasına izin verilmeyen bu Toteh kristali bir tek ortak rüya havuzunda bir başkasının eline verilir. Kristalini başkasının eline veren onun rüyalarına, 
belleğine, hayallerine, anılarına girmesine izin vermiş olur. Böylece kimse tek başına salt kendi rüyasını göremez, herkes birbirinin rüyasının içine sızar:

\begin{abstract}
"Herkesin birbirinin rüyasının içinde kaybolduğu, bir başkasının başından geçenleri kendi anıları sandığı ya da kendisini düpedüz bir başkası olarak yaşadığı, farklı kişilerin rüyalarından çalınmış parçalarla kendisine yepyeni bir mazi inşa ettiği, birinin rüyasından kaçarken kendi rüyasını birilerine kaptırdığı, kimi zaman daha güçlü zihinlerin ötekileri ele geçirip salt kendi rüyasını dayattığı, bazen aynı anı paylaşan eşit güçteki iki farklı rüyanın yarışırcasına birbirinin resimleri arasına karıştığı olurdu." (s.510)
\end{abstract}

Ortak rüya havuzu ayinlerinde kimileri insanlığın ortak belleğine kadar uzanan bir yolculuğa çıkar. Atalardan kalma en ilkel dürtülere, en yabanıl duygulara doğru gerilerken bir daha geri dönmek mümkün olmayabilir. Bu uygulamada sakat kalan, rüya bağı boynuna dolanan, kendisine geri dönemeyen kişiler olur:

\begin{abstract}
"Herkesten bu denli sakınıp saklanan kristal, bir tek ortak rüya havuzu deneyleri sırasında sahibi tarafından bir başkasının eline, kendisinin kapısını açacak bir anahtar gibi verilir; kristalini bir başkasının ellerine teslim eden, bir diğerinin kendi benliğine, belleğine, rüyasına, hayallerine, anılarına girmesine izin vermiş olurdu. O günlerden hatırladığım bu ortak rüya deneyleri sırasında herkesin pek çabuk uykuya daldığıydı; uykusuzluk hummasına tutulmuş en gece düşmanı gözler bile havuza uzandığı anda suya, uykuya, kristalin kalbindeki ışı̆̆a teslim olur; bir nehrin akıntısına kapılmış gibi kendini bir anda çok parçalı bir rüyanın canlı, hareketli resimleri içinde bulurdu" (s. 509).
\end{abstract}

Rüya havuzunda yapılan deneylerde hastalar bazen başka birinin zihninin derinliklerine, geri dönüş yolunu bulamayacak kadar dalıp kaybolurlar. Başkasının zihninin kapısını açıp içeri girmek, çoğu kez insanlığın ortak belleğine yapılan tehlikeli bir yolculuğa dönüşebiliyordu. Atalardan kalma en ilkel dürtülere, en yabanıl duygulara doğru gerilerken parçalanıp dağılmak, bir daha toparlanamamak her zaman mümkündür. Sayrılanmış da olsa kimi güçlü zihinlerin, kendi rüyasına uğrayanları ele geçirir; bu nedenle ortak rüya havuzunda bazı kurbanlar verilir. Rüya bağı boynuna dolanıp, gittiği yerden dönemeyenler de olur (s. 511). Başkasının zihnine girip onun rüyasını görmek, onun zihnine nüfuz etmek fantastik bir olaydır. Yazar, rüya havuzu deneyleri ile kahramanlarını fantastik bir yolculuğa çıarırken, okuyucuları da bu yolculuğa tanıklık etmeye davet eder.

\title{
Avona'nın saçlarının alev alması
}

Agabu, eşi Zeheyra'yı, ona çok benzeyen Avona ile aldatır. Agabu, uzak dağ köylerinden birinde yaşayan Avona'yı görmeye gittiği bir zamanda ortada hiçbir sebep olmamasına rağmen ateş, yanıcı, yakıcı hiçbir madde yokken Avona'nın saçları birden tutuşmaya başlar. Alev alan saçları zorlukla söndürülür. Tutam tutam kopan saçları yerde yanmaya devam eder. Durup dururken saçlarının alev almasının sebebini, "birinin uzaktan tutuşturmasına, saçının tellerinin uğradığı bu belalı büyüye anahtar olmasına" (s. 404) bağlanır.

\subsection{Fantastik hayvanlar}

\section{Gölge kuşu}

Anakara'daki önemli fantastik hayvanların başında Gölge Kuşu gelir. Sayıları azdır ama uzun yaşarlar. Sabırlı, sakin, bilge olarak nitelendirilen Gölge kuşlarının en genci bile insanların atalarının atasını tanır. Adına Gölge Kuşu denmesinin sebebi ise: 


\begin{abstract}
"Kanatlarının gölgesi toprağa düştüğünde hiçbir insan o gölgeye basamazmış. Gölgeleri tabiatın bilinmez güçleri tarafından kutsanmıştır onların, güneş üstlerine vurduğunda elbet toprağa düşer gölgeleri, ama hiçbir insan ayağı çiğneyemez! En atik ayak, en çevik adım bile gölge kuşunun kanadının toprağa benekler gibi düssen kutlu gölgesine basamamıştır bugüne dek. Gölge kuşlarının gölgesine basacağım diye uğraşıp kendi etrafinda çırpına çırpına dönerek çıldıranlar olmuştur.” (s. 110)
\end{abstract}

Anakara'daki diğer bazı hayvanları birer cümlecikle özetlenecek olursa, karaya yaklaşan gemilerin bordasına konan, onların karaya yaklaştıklarının habercisi olan ve bu yüzden "Gemi Karşlayan" da denilen "Karakuşu”; genellikle ağır hareket eden yeşil kanatlı, kırmızı gagalı, boncuk gözlü Sak güvercinleri; nesli tükendiği söylenen taoma domuzu; koyu yapraklı çatallı dallar arasında yalnızca gözleri görülüp hırıltıları duyulan vahşi tuaranaglar; açık denizlerin en büyük balıklarından biri olan ohorazolar; hem derileri hem gözleri benekli olan deniz inekleri; koşum hayvanı olarak eğitilen beyaz eşek ve zebra kırması düşük kulaklı sevimli "Nabetra"lar; önemli, ivedi haberlerin emanet edildiği, gökyüzünde yıldırım hızıyla uçarken ardında beyaz köpüklü bir iz bırakan, sert ve keskin kanatlarının yoluna çıkan bulutları biçip geçmesi nedeniyle "Bulutbiçen" de denilen bir tür kartal ve şahin kırması olan "Kılıçkanat" kuşu dikkat çekmektedir.

\title{
2.6. Fantastik bitkiler
}

\section{Gaveleana menekşesi}

“Renkleri gibi acı mor kok”an (s. 135) Gaveleana menekşesi oldukça ilginç bir bitkidir. Gaveleana menekşesi sadece kadınların elinden su içer ve sadece erkeklere kokar. Hiçbir erkeğin elinden su içmediği gibi hiçbir kadına da kokmaz:

"Gaveleana menekşesi ancak kadınların elinden su içen doğanın sihirli çiçeklerinden biri. Yağmur suyuyla besleniyor ama bir tek erkeklere kokuyor. Bugüne kadar hiçbir kadına kokmadığı biliniyor. Tıpkı hiçbir erkeğin elinden su içmediği gibi” (s. 135)

Yazar; mekânıyla, zamanıyla, kişileriyle, olaylarıyla yeniden tasarladığı Yerküre gezegeninin Anakara parçasında yetişen bitkileri de fantastik yönleriyle ön plana çıkarır. Taşıdığı özellikler itibariyle gaveleana menekşesi bunun tipik bir örneğidir.

\section{Moksha bitkisi}

Sağlık Yurdu'ndaki ruh sağaltıcıları, Rüya Terbiyecileri tarafından orada tedavi görenlere moksha bitkisinin soma yaprakları çiğnettirilir. Gerçeğin üzerindeki örtüyü kaldırdığına inanılan bu bitkinin gözü, aklı ve ruhu zenginleştirerek algı kapılarını açtığı kabul edilir. Algı sınırlarını genişleterek gerçeği görünür kılan moksha bitkisi bu özelliğiyle fantastik kabul edilebilir.

\subsection{Fantastik nesneler}

\section{Görünmez mürekkep}

Bilge Şair Bendag, gönüllü sürgün hayatından döndükten sonra Anakara'da yapacağı yolculuktaki şiirlerini görünmez bir mürekkeple kaleme alır. Son Yolculuk başlığı altında topladığı şiirlerini eski ama güvenli bir yazı gizleme yöntemi olan görünmez mürekkeple incecik parşömenlere, defterlere yazar. Böylece bu şiirlerini yabancı gözlerden, kirli meraklardan gizlemiş olur. Şairin son dönem şiirlerini görünmez bir mürekkeple yazmasının sebebi, elli yll önce ortadan kaybolduğu ve bir daha kimsenin onu 
görmediği gibi, “onları da kendisi gibi görünmez kllmak iste”mesidir (s. 13). Nitekim Bendag, Odragend'de gözaltına alındığında çantasından çlkan defterleri inceleyen polis müdürü Tauro, bu defterlerdeki görünmez mürekkeple yazılan şiirleri göremez. Defterlerin içi boş sanır. O defterlerdeki görünmez mürekkeple yazılan şiirleri yalnızca Bendag görür. Bendag, Tauro'nun o şiirleri görememesinden, görünmez mürekkebin defterin sayfalarını boş gösteriyor olmasından ötürü sevinç duyar, şiirlerinin de kendisi gibi saklanmayı bildiğine ve güvende olduğuna sevinir.

\title{
Uyku cini motifli Serquvaa kilimleri
}

Yataklara, sedirlere üzerlerinde uyku cini motifi olan serquvaa kilimleri, örtüleri serilir. Bu tılsımlı kilimlerin özelliği uykuya dalmakta zorluk çekenleri, uyuyamayan yaşlıları, yaşam bezginlerini, ruh yorgunlarını, öğle uykusuna yatmakta zorluk çeken haşarı çocukları hemen uykuya çeker. Uyku problemi olanları uykuyla barıştırır, onlara rahat bir uyku sunar. Moottah, Zeey ve Tagan'la konakladıkları bir konuk evinde yataklara serilen uyku cini motifli kilimleri görünce onlara şu açıklamayı yapar: "Başınızı kilimlerde betimlenen Uyku Cinleri’nin dizlerine koyduğunuzda rahat, ferah bir uyku çeker; ışıklı, hafif rüyalar görürsünüz. Uyandığınızda içiniz aydınlıkla yıkanmış olur. (...) Aksi ihtiyarları, huysuz çocukları uykuyla barıştıran bu tılsımlı kilimler, bütün evlerin gözdesi, hanların, kervansarayların uğuru" (s. 362) olarak kabul edilir.

\section{Toteh kristali}

Rüya havuzu tekniğinde kullanılan tılsımlı bir nesnedir. Toteh kristalleri insanların kişisel kayıtlarını tutar, onların duygularını, düşüncelerini, hayallerini saklar. Rüya havuzu uygulamalarında herkesin kendine ait, bir tek kendisinin dokunabildiği bir Toteh kristali vardır. Her kristal, sahibiyle algısal ilişkiye geçtiği için, kendisine bir başkasının dokunması halinde bu algı bulanır. Herkesten korunması gereken Toteh kristallerine başkalarının dokunmasına bir tek ortak rüya havuzunda izin verilir. Kristaline, başkasının dokunmasına izin veren onun rüyalarına, belleğine, hayallerine, anılarına girmesine izin vermiş olur. Toteh kristali rüya havuzu deneyinin vazgeçilmez unsurudur:

\begin{abstract}
"Herkesin yalnızca kendisine ait, bir tek kendisinin dokunabildiği ve herkesten sakınıp koruduğu bir Toteh kristali vardı. Nasıl kadim taşlar yüzyıllardan beri yerkürede olup bitenlerin kaydını tutuyorsa, tılsımlı Toteh kristalleri de insanların kişisel kayıtlarını tutar, onların duygularını, düşüncelerini, anılarını, hayallerini saklardı. Her kristal sahibiyle algısal ilişkiye geçtiği için, kendisine bir başkasının dokunması halinde bu algı bulanır, kirlenir, hatta kimi zaman hasara uğradığı olurdu. Onu arada bir zamanın tozundan, kötü hatıraların biriktirdiklerinden temizlemek gerekir; bunun için belli aralarla yanardağ külleriyle ovulup, açık denizlerin tuzlu suyuyla yıkanıp, ay ışı̆̆ından geçirilerek arındırılırdı." (s. 509)
\end{abstract}

Herkesin yalnızca kendisine ait Toteh kristalinin dışında, rüya havuzunun tepesinde dev bir avize gibi duran bir kristal de vardır. Rüya havuzunda herkesin uykuya çabucak geçmesini bu kristal sağlar. "Küçük boy bir kaya parçası büyüklüğündeki bu çokgen yüzeyli kristal, kendi etrafında ağır ağır dönerken üzerine vuran aydınlığı, altındaki havuzda gözleri kapalı yatanların üstüne serperek onlara rüyaları için gereken ışı̆̆ı sağlar” (s. 509). Gerek insanların duygularını, düşüncelerini, hayallerini, anılarını, belleğini, kişisel kayıtlarını tutmasıyla; gerekse de başkasının bunlara erişimini sağlamasıyla Toteh kristali fantastik bir nesne addedilebilir.

\section{Sonuç}

Gerçekliğin çiğnendiği fantastik, bir kaçış edebiyatıdır. Modern hayatın bireylere dayattı̆̆ı hızlı yaşama tutkusu bireyi bunalıma sürükler, onu farklı arayışlara sevk eder. Modern hayatta birey, her şeyi yarına, 
geleceğe yönelik tasarlarken bugünü kaçırmaktadır. Yarına endekslenmiş bir hayat, bugünü kolayca gözden çıkarabilmektedir. Fakat bu her zaman herkes için mümkün olmaz. Bu dünyada aradığını bulamayan birey, bu dünyadan kaçmanın yollarını arar. Bu yolla sanatçı, modern dünyada bulamadığı huzuru, mutluluğu dileğince kurguladığı dünyada aramaktadır. Kendi gönlünün istediği şekilde var ettiği bu yeni dünyada sadece kendi özlemlerini yansıtmakla kalmaz, okurunun merakını kamçılayarak onu da bu dünyaya davet eder ve böyle bir dünyanın hayalini ona da aksettirir. Murathan Mungan'ın Şairin Romanı'nda yaptığı tam da budur. Modern hayatın baskısından bıkan bireyleri bambaşka bir hayata davet eder. Burada her şey huzuru çağrıştırmaktadır. Zamanın daha sakin aktığı, doğanın bütün ihtişamıla huzur ve dinginlik verdiği, genelde sanatın özelde ise şiirin baş tacı edildiği, insanların büyük bir yaşama tutkusuyla hayata bağlandığı bir dünyadır. Elbette bu dünyada her şey iyilikten ibaret değildir. İyiliğin yanında kötülük de mevcuttur. Cinayetlerin işlendiği, hırsızlığın yapıldığı bu fantastik dünyada yazar, iyiliğin olduğu yerde kötülüğün de olabileceğini tıpkı her masalın sonunda olduğu gibi burada da kötüleri cezalandırarak, iyileri ve iyiliği ödüllendirerek gösterir. Ana izleğini şiir, şair, yolculuk, yaşlılık, doğa gibi kavramların oluşturduğu Şairin Romanı kitapta da ifade edildiği gibi tabiata, emeğe ve şiire övgünün romanıdır.

Şairin Romanı'ndaki fantastik kişiler incelendiğinde doğaüstü güçlere sahip olan romandaki kişilerin taşıdıkları fantastik yönleri belirlenmiştir. Buna göre kimi karakterler kehanetleriyle yer alırken, kimileri de fantastik edebiyatın temel izleklerinden olan ikizleşme motifiyle ön plana çıkmaktadır. Olayların geçtiği yer açısından bakıldığında Şairin Romanı'ndaki en baskın unsurun mekân olduğunu söylenebilir. Tamamen farklı bir dünyada geçen olayların yaşandığı eserdeki mekân, olağanüstü özelliklere sahiptir. Özellikle şairlerin şairliğini onaylayan, özgün ve taklitçi şairleri birbirinden ayıran "Şairin Kuyusu” bu olağanüstü yönüyle dikkat çekmektedir. Şairin Romanı'nda zaman unsuru ise kişiler, mekân ve olaylar kadar baskın yer tutmamaktadır. Fakat yine de burada yaşadığımız dünyadan farklı bir zamanın olduğu söylenebilir. Burada zaman farklı dilimlere ayrılmış, her zaman dilimine farklı adlar verilmiştir. Fantastik olaylar ise Şairin Romanı'ndaki bir diğer önemli unsurdur. Ruh sağaltma yöntemi olarak kullanılan “yerine geçme ayini”nden, insanların birbirlerinin rüyalarına müdahale ettiği "rüya havuzu" seanslarına kadar bir dizi fantastik olay yaşanır. Romanda önemli fantastik hayvanlar, bitkiler, nesneler de yer almaktadır. Olağanüstü özelliklere sahip bu bitkiler, hayvanlar, nesneler romanın fantastik kurgusunu pekiştirmektedir.

Şairin Romanı, gerek olayların yaşandığı zaman ve mekan bakımından gerekse de olağanüstü özellikler göstermesiyle fantastik; herkesin şiirle ilgilendiği, şiirin kutsandığı, deyim yerindeyse şiirsel bir dünya kurgusuyla ütopik; olayların cinayetler etrafında gelişmesi ve çözülmesiyle polisiye; yazarın şiirle ilgili görüşlerini yansıtmasıyla da poetik bir metin niteliği taşır. Olmayan bir gezegen yaratıp yeni bir dünya kurması, okuyuculara bambaşka bir âlemin kapılarını açması Mungan'ın romanını tek başına fantastik kılan özellikler değildir. Bunların dışında fantastiğin "rüya”, "ikizleşme” gibi izleklerini kullanması da eseri fantastik kllar.

Sonuç olarak çalışmamızda da tespit ettiğimiz gibi Şairin Romanı adlı eser, bu dünyadan farklı bir gezegende doğaüstü güçlere sahip kişiler ve olağanüstü olayların yaşandığı fantastik bir eserdir. Mungan, fantastik türün doğasından kaynaklanan etkiyle okurlarını yarattığı kurmaca âlem üzerinde düşünmeye, sorgulamaya davet eder. 


\section{Kaynakça}

Aslan, P. (2010). Osmanl//Türk Modernleşmesinin Gölgesinde Varla Yok Arası Bir Tür: Fantastik Roman (1876-1960). (Yayımlanmamış Doktora Tezi). Boğaziçi Üniversitesi/Sosyal Bilimler Enstitüsü, İstanbul.

Börekçi, G. (28.04.2013). "Murathan Mungan: Sol hülyaları olan bir yazarın ütopyasını yazdım."

http://egoistokur.com/murathan-mungan-sol-hulyalari-olan-bir-yazarin-utopyasini-yazdim/ (Erişim Tarihi: 25.10.2017)

Erciyes, C. (o8.04.2011). “Arenayla Opera Arasında Bir Hayat Benimkisi.”, Radikal gazetesi.

http://www.radikal.com.tr/kitap/arenayla-opera-arasinda-bir-hayat-benimkisi-1045625/

Tarihi: 18.10 .2017$)$

(Erişim

Mungan, M. (2011). Şairin Romanı. İstanbul: Metis Yayınları.

Özlük, N. (2011). Türk Edebiyatında Fantastik Roman. İstanbul: Hiperlink Yayınları.

Steinmetz, J.L. (2006). Fantastik Edebiyat. Nemli, H. Fehmi. (Çev.). Ankara: Dost Kitabevi Yayınları.

Şener, S. (2012). "Yerküre Yazılmak için Vardır”, Notos Öykü Dergisi. S. 33, s. 84.

Taş, İ. (2009). 1980- 200o Arası Türk Hikâye Kitaplarında Fantastik Unsurlar. (Yayımlanmamış Yüksek Lisans Tezi). Pamukkale Üniversitesi/Sosyal Bilimler Enstitüsü, Denizli.

Todorov, T. (2012). Fantastik: Edebi Türe Yapısal Bir Yaklaşım. N, Öztokat. (Çev.). İstanbul: Metis Yayınları.

Uğur, V. (2009). 1980 Sonrası Türk Edebiyatında Popüler Roman. (Yayımlanmamış Doktora Tezi). İstanbul Üniversitesi/Sosyal Bilimler Enstitüsü, Istanbul.

Yllmaz, O. (05.05. 2011). "Şairin Romanı: Mungan’ın Başyapıtı". Sabitfikir.

Yüksel, S. (2012). "Muhtevası Ve Kaynakları Bakımından Şairin Romanı". Yeni Türk Edebiyatı Araştırmaları. Y. 4, S. 8, Temmuz-Aralık 2012, s. 17-34. 